\title{
The influence of electrical potential on the mechanical properties of commercially pure titanium
}

\author{
K. A. Osintsev ${ }^{1,2}$, I. A. Komissarova ${ }^{3}$, S. V. Konovalov ${ }^{\dagger, 1,2}$, S. V. Voronin ${ }^{2}$, X. Chen ${ }^{1,2}$ \\ †ksv@ssau.ru
}
${ }^{1}$ Wenzhou University Institute of Laser and Optoelectronic Intelligent Manufacturing, Wenzhou, 325024, China ${ }^{2}$ Samara National Research University, 34 Moskovskoye shosse, Samara, 443086, Russia
${ }^{3}$ Siberian State Industrial University, 42 Kirova St., Novokuznetsk, 654007, Russia

\begin{abstract}
The mechanical behavior of metallic materials exposed to external energy sources e.g. electric potentials, direct and pulsed currents as well as magnetic fields is a key aspect in assessing the material usability in present day industries. Recent researches have shown that the mechanical properties of materials are sensitive to the state of thin near-surface layers. This state can be changed by an electrical potential that can influence on the energy density of the surface. The paper discusses the effect of electrical potentials (values from 0 to $1 \mathrm{~V}$ ) on the mechanical properties (microhardness and elastic modulus) of the commercially pure titanium grade 2 . It was revealed that the microhardness increased by $11 \%$ at $1 \mathrm{~V}$ compared to the initial state. As regards elastic modulus, its values gradually increased from around $100 \mathrm{GPa}$ at $0 \mathrm{~V}$ to $300 \mathrm{GPa}$ at $1 \mathrm{~V}$. It has been suggested that the increase of the microhardness and elastic modulus relates to the changes in surface tension of titanium samples. An analysis of the surface tension's dependence upon an electrical potential was carried out in terms of an electric double layer concept. It was shown that the surface tension coefficient has quadratic dependent on electric potential.
\end{abstract}

Keywords: electric potential, microhardness, elastic modulus, titanium.

УДК: 539.213:669.017

\section{Влияние электрического потенциала на механические свойства технически чистого титана}

\author{
Осинцев К. А. ${ }^{1,2}$, Комиссарова И. А. ${ }^{3}$, Коновалов С. В. ${ }^{\dagger, 1,2}$, Воронин С. В. ${ }^{2}$, Чэнь С. ${ }^{1,2}$ \\ ${ }^{1}$ Университет Вэньчжоу, Институт лазерного и оптоэлектронного интеллектуального производства, \\ Вэньчжоу, 325024, Китай \\ ${ }^{2}$ Самарский национальный исследовательский университет им. академика С. П. Королёва, \\ Московское ш., 34, Самара, 443086, Россия \\ ${ }^{3}$ Сибирский государственный индустриальный университет, ул. Кирова, 42, Новокузнецк, 654007, Россия
}

\begin{abstract}
Механическое поведение металлических материалов, подвергаемых воздействию внешних источников энергии, таких как электрические потенциалы, постоянные и импульсные токи, а также магнитные поля, является критическим аспектом при оценке применимости материала в современных отраслях промышленности. Ранее проведенные исследования показали, что механические свойства материалов чувствительны к состоянию тонких приповерхностных слоев. Это состояние может быть изменено наложением электрического потенциала различной величины, который может влиять на плотность энергии поверхности. В данной статье рассматривается влияние электрических потенциалов (в интервале значений от 0 до 1 В) на механические свойства (микротвердость и модуль упругости) технически чистого титана марки BT1-0 (иностранный аналог grade 2). Было показано, что при подключении электрического потенциала от источника постоянного тока на интервале от 0 до 0.1 В микротвердость образцов технически чистого титана ВТ1-0 увеличивается до 11\% по сравнению с исходным значением микротвердости, в то время как значение модуля упругости возрастет от 100 ГПа (значения с исходном состоянии) до 300 ГПа при наложении к образцам электрического потенциала 1 В. Было высказано предположение, что увеличение значений микротвердости и модуля упругости связано с изменениями поверхностного натяжения образцов титана. Выполнен анализ зависимости поверхностного натяжения от электрического потенциала в рамках концепции двойного электрического слоя, в результате которого было показано, что коэффициент поверхностного натяжения имеет квадратичную зависимость от электрического потенциала.
\end{abstract}

Ключевые слова: электрический потенциал, микротвердость, модуль упругости, титан. 


\section{Introduction}

Recently, many researchers have argued the use of external energy sources, e.g., electrical and magnetic fields, pulsed and direct electrical currents, represents an intensively developing research domain in the field of plastic deformation in metallic materials [1-5].

A constant magnetic field is supposed to affect the mechanical behavior of mono- and polycrystalline materials in the process of plastic deformation $[6,7]$. Studies $[6,7]$ have revealed the maximum percent reduction of microhardness to be $12.5 \%$ if exposed to a magnetic field. It has been demonstrated that microhardness varies depending on the exposure time to a magnetic field. As soon as uncoupled with an external energy source, its value is as much as a reference one. An electrical field, currents and potentials of various values, applied to metal either in processes of heat treatment [8] or at ambient temperature [9], may initiate the modification of its structure and plastic properties. It is reported on nanocrystallization [10], the modification of texture, and the advancement of plastic properties provided that electrical current pulses flow through samples of nonferrous metals in a diversity of technological processes $[11,12]$.

An electric potential arising either due to the direct current supply or via the coupling of two different metals may change their microhardness, a creep rate, as well as residual stress and the dislocation substructure [13-15]. At the same time, changes in mechanical properties, such as microhardness, as a result of the action of the electric potential, are temporary, and their values return to their original values within 10 minutes [13]. An electrical potential of $5 \mathrm{kV} / \mathrm{m}$ was used in the artificial aging of an aluminum alloy at a temperature of $180^{\circ} \mathrm{C}$ over 22 hours alongside with the activated disintegration of an oversaturated solid solution, microhardness increases because a density of the excess phase rises compared to a dispersion-hardened alloy without an electric potential [8].

The effect of the electric potential on the mechanical behavior of porous Ni-based metallic nanostructures was in the focus of authors [16]. The study by nanoindentation has pointed out that the electric potential modifies electrical and atomic structures of nano-structural surfaces. A proportional relationship has been suggested, revealing the electric potential increase causes elastic modulus growth.

A study [17] has reviewed the importance of the electric potential for the microhardness of aluminum, cobalt, zinc, zirconium, and iron. The finding to emerge from this study is the microhardness of aluminum, cobalt, and zinc, having a negative Hall coefficient (electron conductivity) [18] drops down by $5-20 \%$. In contrast, the microhardness of zirconium and iron, which have a positive Hall constant (hole conductivity), rises by $10 \%$.

It is reported [19] on the charging of a surface in $\mathrm{SiO}_{2}$ nanoparticles by ultraviolet rays. The researchers have come to a conclusion charged nanoparticles in a polymer composite may increase its strength and elastic modulus by $\sim 2 \%$ and $\sim 48 \%$, respectively.

A double electrical layer to raise total energy in the system "conductor-double layer" is generated when affecting a metallic conductor by the electrical field and furthers an increase of its creep rate [20].

To sum up, the processing of materials by pulsed electrical currents, electric potentials, and magnetic field initiates changes of their physical and mechanical behavior; however, there is no comprehensive research data of this effect on several materials. One of this materials is titanium which owing to its strength and corrosion resistance, are widely used in a variety of industries [21]. Therefore, this work aims to investigate a previously unexplored role of the electric potential for the mechanical behavior of commercially pure titanium.

\section{Experimental methods}

\subsection{Samples preparation}

For the purpose of research, we tested commercially pure titanium (cp-Ti) grade 2 with the chemical composition: C $0.07 \%$, Fe $0.3 \%$, Si $0.1 \%, \mathrm{O}_{2} 0.2 \%, \mathrm{~N} 0.04 \%, \mathrm{H}_{2} 0.01 \%$, $\mathrm{Ti}$ - balanced. Commercially pure titanium used in research is a polycrystalline material. The average grain size is $25 \mu \mathrm{m}$. Samples with the dimensions of $50 \times 10 \times 5 \mathrm{~mm}$ were cut off from the titanium plate. To prepare the surface of the samples, they were processed by different grades of polishing paper. The sample was fixed on a foiled copper-coated fiberglass plastic FR4 $(100 \times 100 \mathrm{~mm}-$ foiled surface area, $1.5 \mathrm{~mm}-$ thickness of a copper layer, $18 \mu \mathrm{m}$ - thickness of a fiberglass plastic base) with current-conducting glue "Kontaktol" (specific resistance $\rho=1.5 \mathrm{Ohm} \times \mathrm{mm}^{2}$ ). A fiberglass plastic was coupled with a power supply by a $1 \mathrm{~m}$ screened copper cable (diameter $-2.5 \mathrm{~mm}$ ) supposed to be a material to seal off from the object table of a microhardness tester. A copper cable was connected with a fiberglass base via soldering.

\subsection{Microhardness test}

Microhardness was estimated using a microhardness tester HV-1000. An indentation load was set $0.1 \mathrm{~N}$, a load time $-10 \mathrm{~s}$. Samples were coupled with a positive terminal of a programmed power source Rigol DP811 to supply an electrical potential. The second terminal of the power supply was earthed. A wiring diagram, which is given in Fig. 1, is similar to one used [22]. Microhardness was measured at a room temperature of $22^{\circ} \mathrm{C}$.

The prior research has established the effect of interest is independent of an electric potential sign and a significant effect of the electric potential on the microhardness of metal materials was found only at small values, up to $5 \mathrm{~V}[17,22]$. At the same time, after $1 \mathrm{~V}$, a further increase in the value of the electric potential does not lead to a change in the mechanical properties, values remain stable. Therefore, microhardness was measured only for positive values ranging from 0 to $1 \mathrm{~V}$ at an interval of $0.05 \mathrm{~V}$.

Microhardness was assessed in 30 minutes after a sample had been connected with a stabilized power source. Microhardness was tested a minimum 15 times for each electric potential value. The data on microhardness were processed statistically according to direct measurements; an error bars were determined with a $95 \%$ reliability rate. 


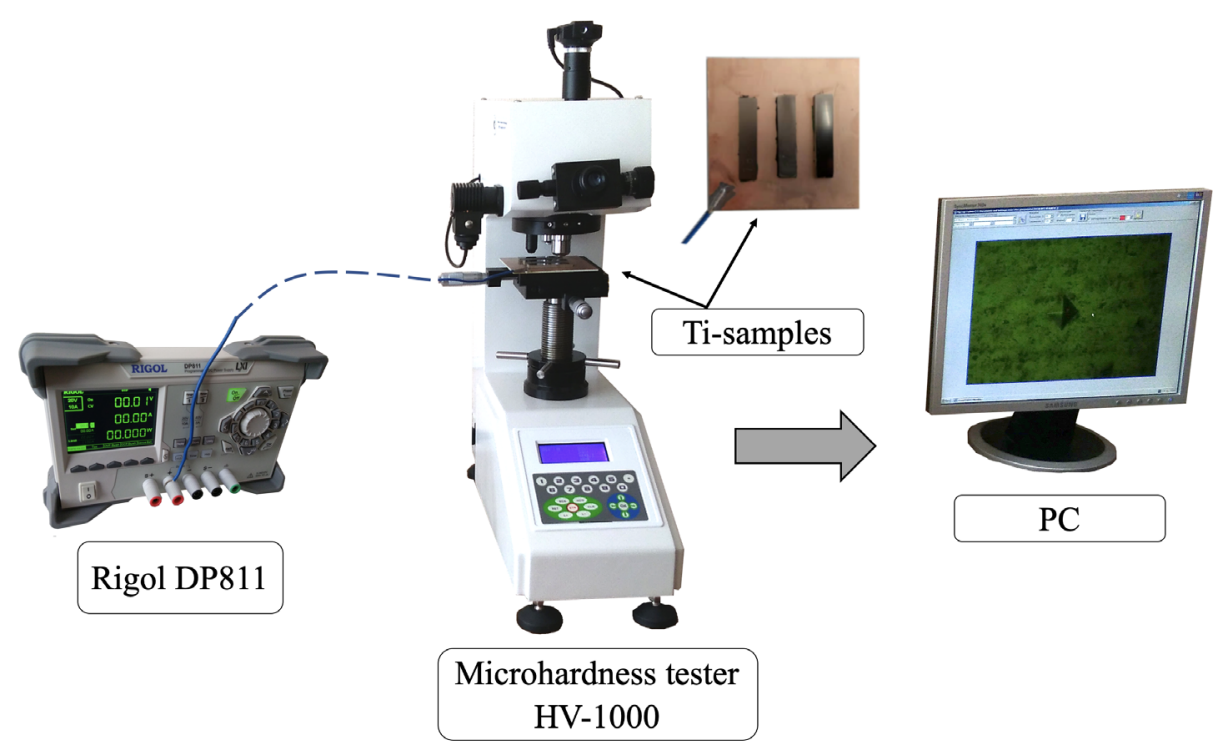

Fig. 1. (Color online) Wiring diagram of the electric potential supply with Ti-samples when testing microhardness.

\subsection{Nano-indentation test}

Mechanical properties were assessed by the method of nano-indentation as given in SO 14577-1:2002. Metallic materials - instrumented indentation test for hardness and materials parameters - Part 1: test method. The measurement method is that a probe sensor is moving along a normal line to a sample surface (amplitude less than $10 \mathrm{~nm}$, frequency $\sim 10 \mathrm{kHz}$ ) contacts with the surface. Since a tip contacts with the material, a frequency of probe sensor oscillation goes up as forced more against the surface. The mathematical formulation based on the Hertz model says an inclination angle of a function oscillation frequency vs. penetration depth (force curve) is proportional to an elastic modulus of the material being tested [23].

Before measurement, calibration was carried out on standard materials with a known elastic modulus. An elastic modulus value is determined according to the correlation between inclination angles of force curves for being tested and standard materials.

Fig. S1 (Supplementary Information) presents a wiring diagram of the electric potential supply with a sample to measure an elastic modulus.

Titanium samples fixed to a fiberglass base, therefore, connected with a positive terminal of a direct current supply Rigol DP8111 were on the object table of a nanohardness tester Nanoscan 3D. Elastic modulus vs. electric potential value was measured at an interval of $0.1 \mathrm{~V}$.

\section{Results and discussion}

\subsection{Microhardness indentation analysis}

The data on the microhardness of $\mathrm{cp}$-Ti vs. a supplied electric potential are given in Fig. 2.

A reference value of microhardness (i. e., with no electric potential) is as much as $180.2 \pm 5.24 \mathrm{HV}$. Once an electric potential of $0.01 \mathrm{~V}$ was applied, it demonstrated a slight

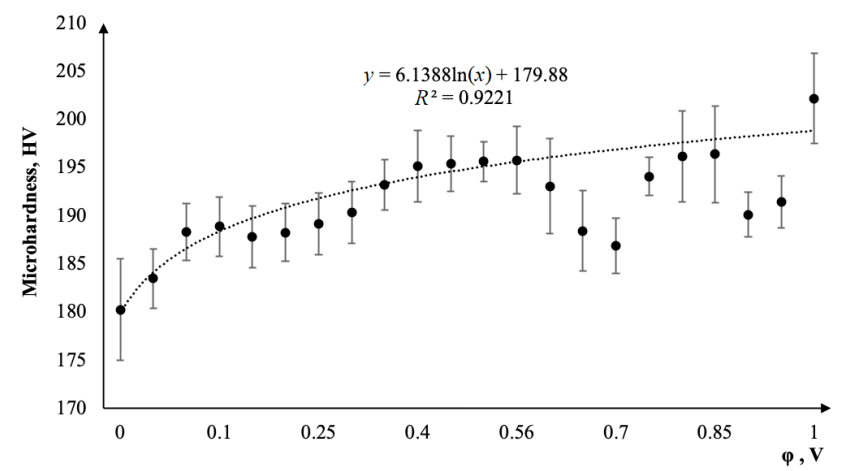

Fig. 2. Microhardness of commercially pure titanium vs. electric potential.

change, being $183.51 \pm 3.09 \mathrm{HV}$. The further rise of applied electrical potential to $0.55 \mathrm{~V}$ resulted in a microhardness increase up to $195.78 \pm 3.51 \mathrm{HV}$. For an electric potential varying from 0.55 to $0.75 \mathrm{~V}$ microhardness dropped to a minimal value of $186.9 \pm 2.90 \mathrm{HV}$ in this range. Microhardness rose up to $\sim 196 \mathrm{HV}$ for an electric potential of $0.8 \mathrm{~V}$ and $0.85 \mathrm{~V}$, decreasing then to $190.13 \pm 2.31 \mathrm{HV}$ at $0.9 \mathrm{~V}$, and going up to $202.21 \pm 5 \mathrm{HV}$ at $1 \mathrm{~V}$. From the data obtained we can conclude the electric potential brings about an approximately $11 \%$ increase of the surface resistance to penetration.

Generally speaking, a relationship between an electric potential varying from 0 to $1 \mathrm{~V}$ and the microhardness of titanium complies with a maximal percent change of microhardness (16\%) reported in other studies [20,22]. Fig. S2 (Supplementary Information) presents the differences between the sizes of traces that have been left by the indenter during the microhardness test.

Sizes of traces decrease from 31.2 to $30.3 \mu \mathrm{m}$ with increasing of electric potential. Although this change seems to be insignificant, it relates to the increase of microhardness by $10 \%$. 


\subsection{Load indentation depth analysis}

Assessing more precisely the effect of applied electric potential on samples of $\mathrm{cp}-\mathrm{Ti}$, the elastic modulus was measured according to a force curve height. Fig. 3 shows an applied load and a resulting depth of indention curves for samples of commercially pure titanium.

The curve inclination is proportional to the material elastic modulus in a contact area. From the data in Fig. 3 it is apparent that the curve inclination increases if an electric potential is raised.

\subsection{Effect of electric potential on the elastic modulus of commercially pure titanium}

Fig. 4 presents a graph of an elastic modulus of CP-Ti vs. an electric potential varying from 0 to $1 \mathrm{~V}$.

A reference elastic modulus is $109.85 \pm 8 \mathrm{GPa}$, complying with the data given in reference literature ( 104 GPa) [24]. The supply of a variety of electric potential values leads to a monotonous growth of the elastic modulus, being maximal $329.09 \pm 30 \mathrm{GPa}$ at $1 \mathrm{~V}$; that is approximately three times higher than a reference value. This dependence is approximated most precisely by an exponential function (an approximation factor $R$ of 0.979 ).

The surface tension is relevant for the work necessary to develop a new surface when destructing a solid. The hardness to be estimated by methods employing the surface dispersion may be determined as the dispersion work per unit of a patterned surface [25]. In a majority of methods to assess microhardness, this value is proportional to the surface energy $\mathrm{HV}=d A / d S \approx k \sigma$, where $d A / d S$ - an amount of work to form a new surface when destructing a solid, $k-$ a nondimensional proportionality constant to characterize the process inconvertibility, $k \sim 10^{3}, \sigma-$ the surface tension of a metal.

Considering the configuration of curves in Fig. 2 and Fig. 4, we assume surface tension vs. electric potential dependence can demonstrate the same nature. A dependence surface tension vs. electric potential plotted in line with (3) is presented in Fig. 5.

To analyze the dependence of the surface tension upon an electric potential, we use the concept of a double electrical layer. As suggested in [25], an electron cloud of surface atoms is in a particular state if compared to atoms below the sample surface, being a reason, therefore, for the formation of a double electrical layer on the surface. Like "a condenser" a double layer on the surface catches electrons as an electron

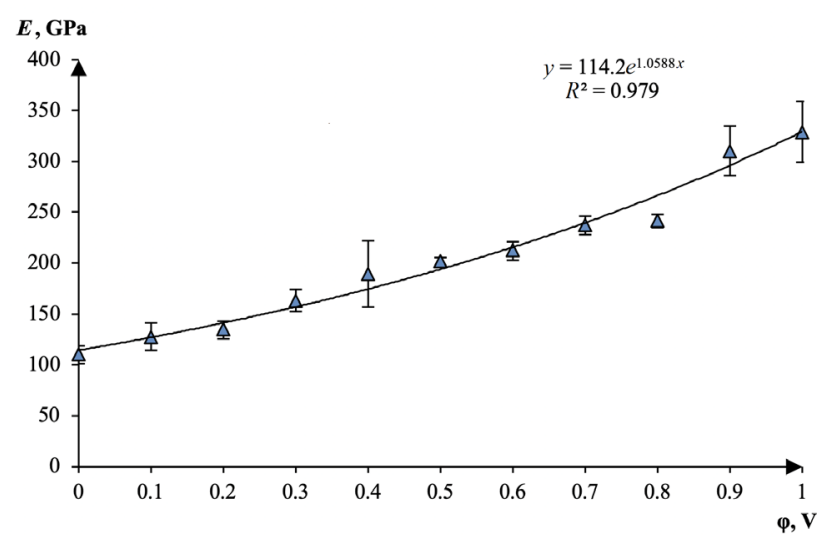

Fig. 4. Elastic modulus of titanium vs. electric potential.

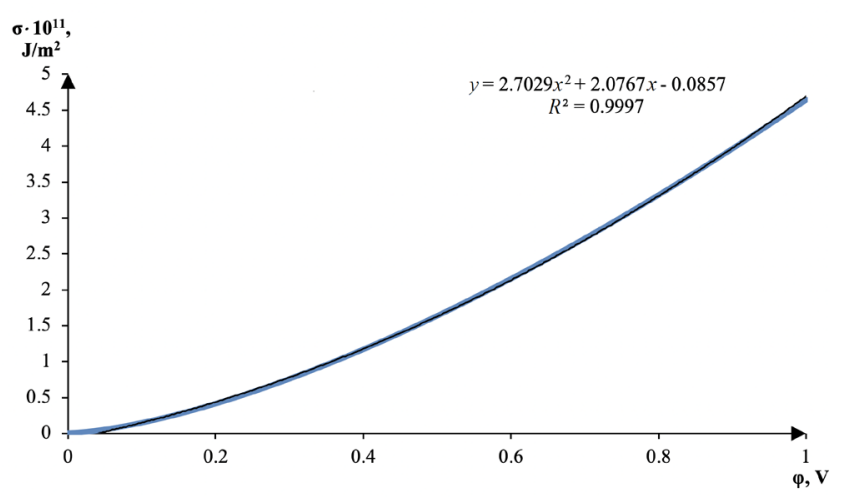

Fig. 5. The surface tension of titanium calculated according to an electric potential.

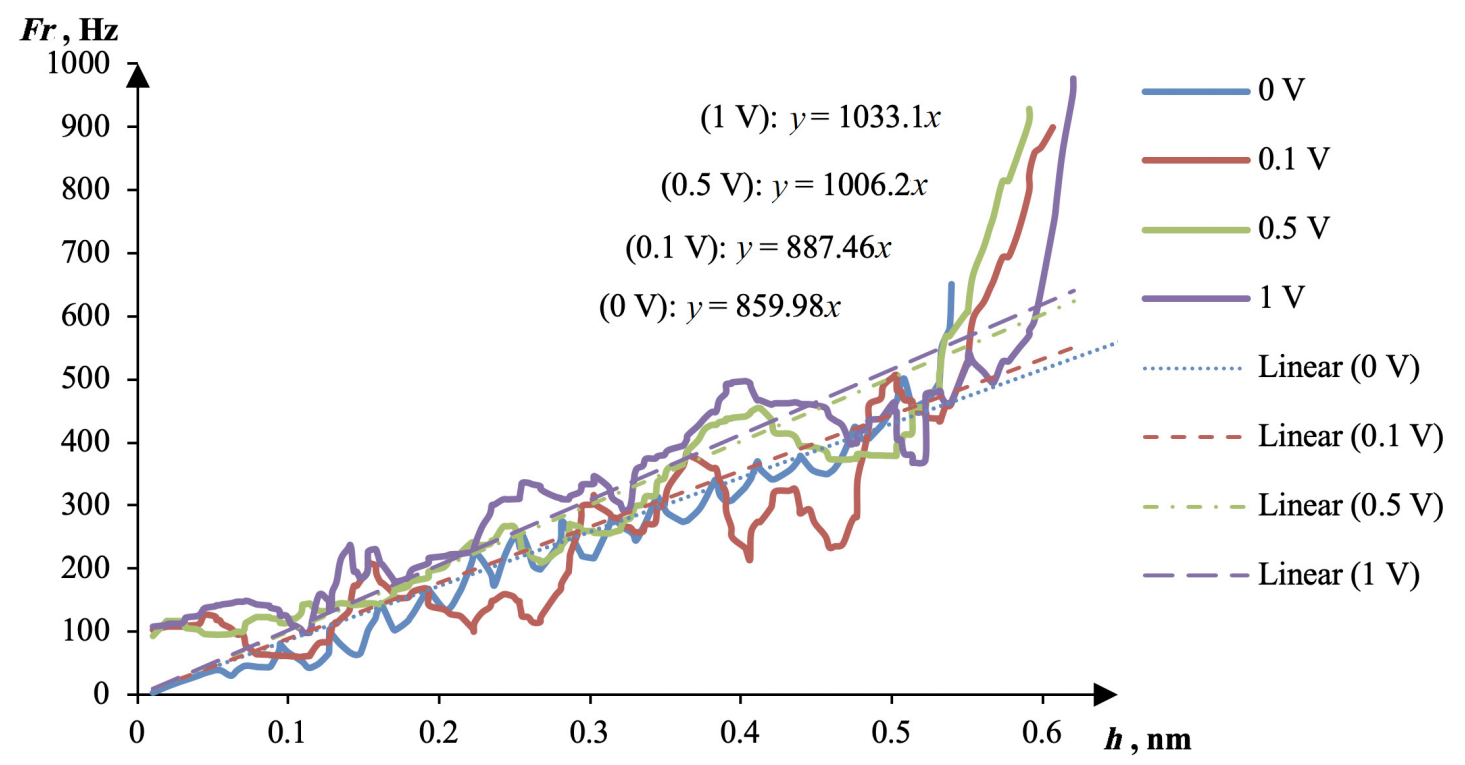

Fig. 3. (Color online) Approach curves of commercially pure titanium at various electric potentials. 
cloud is "distorted" due to the supply of an electric potential. In this case, a density of electrons $n$ in a double layer is higher than without an external potential; as a consequence, the Hall coefficient drops. As given in [25], the surface tension coefficient correlates with the Hall constant $R_{H}$ :

$$
\sigma=0.01805\left[21.517\left(\frac{1}{\left|R_{H}\right|}\right)^{7 / 6}-\left(\frac{1}{\left|R_{H}\right|}\right)^{3 / 2}\right] .
$$

It is known $R_{H}=1 /(n e)$, where $n-$ charge carrier number density, $e-$ an electron charge. Considering $n=N / V$, where $N$ - a number of charge carriers, $V$ - surface volume, we obtain $R_{H}=V /(\mathrm{Ne})$. A metal surface capacity at $S \approx 0.0005 \mathrm{~m}^{2}$ and $d \approx 10^{-10} \mathrm{~m}$ ( $d$ represents a distance between a surface and a double electrical layer) is written $C=\varepsilon_{0} \varepsilon S / d \geq 10^{-5} \mathrm{~F}$. As known an equation calculates a condenser potential: $\varphi=q / c$, where $q-$ is a charge in a metal surface layer $(N \cdot e)$. All the above transformations allow the formulation of the Hall constant as: $R_{H}=V / q=V /(\varphi \cdot c)=S \cdot d /(\varphi \cdot c)$. Substituting an expression for $R_{H}$ into the Eq. (1) gives:

$$
\sigma=0.01805\left[21.517\left(\frac{\varphi \cdot c}{S \cdot d}\right)^{7 / 6}-\left(\frac{\varphi \cdot c}{S \cdot d}\right)^{3 / 2}\right] .
$$

\section{Conclusion}

The study revealed the change of microhardness and elastic modulus of commercially pure titanium grade 2 due to the supply of electric potential in a range from 0 to $1 \mathrm{~V}$. The applying of an electrical potential of $1 \mathrm{~V}$ results in an $11 \%$ increase of microhardness $(180.28 \pm 5.24 \mathrm{HV}$ to $202.21 \pm 5 \mathrm{HV}$ ), and three times increase of elastic modulus $(329.09 \pm 30 \mathrm{GPa})$. The dependence of surface tension in a solid upon an electric potential supplied is presented; its exponential nature is shown as well. The growth of elastic modulus and microhardness is suggested to be related to a double electrical layer on the surface of a charged metallic sample, which raises a density of electrons and reduces a Hall coefficient.

Supplementary material. The online version of this paper contains supplementary material available free of charge at the journal's Web site (lettersonmaterials.com).

Acknowledgments. The reported study was funded by Russian Foundation for Basic Research according to the research project № 19-32-50036.

\section{References}

1. J. Krim. Front. Mech. Eng. 5, 22 (2019). Crossref

2. M. Persson. Nat. Mater. 18, 773 (2019). Crossref

3. T. Y. Chien, J. Liu, A. J. Yost, J. Chakhalian, J. W. Freeland, N. P. Guisinger. Sci. Rep. 6, 19017 (2016). Crossref

4. G.-R. Li, F.-F. Wang, H.-M. Wang, R. Zheng, F. Xue, J.-F. Cheng. Chinese Phys. B. 26, 046201 (2017). Crossref

5. Z. Lu, C. Guo, P. Li, Z. Wang, Y. Chang, G. Tang, F. Jiang. J. Alloys Compd. 708, 834 (2017). Crossref

6. D. V.Zagulyaev, K. A. Osintsev, S. V. Konovalov, V.E. Gromov, A.P. Semin. J. Surf. Investig. 11, 1338 (2017). Crossref

7. E.A. Petrzhik, M.O. Stepanyuk, O.G. Portnov, V. V. Antipov. Phys. Solid State. 55, 1442 (2013). Crossref

8. S. Fu, H. Liu, N. Qi, B. Wang, Y. Jiang, Z. Chen, T. Hu, D. Yi. Scr. Mater. 150, 13 (2018). Crossref

9. A. Rahnama, R. Qin. Sci. Rep. 7, 1 (2017). Crossref

10. Y. Ye, S.-Z. Kure-Chu, Z. Sun. Mater. Des. 149, 214 (2018). Crossref

11. R. Zhang, X. Li, J. Kuang. Mater. Sci. Technol. 33, 1421 (2017). Crossref

12. R. Zhu, G. Tang. Mater. Sci. Technol. 33, 546 (2017). Crossref

13. V.I. Danilov, L.B. Zuev, S. V. Konovalov, R. A. Filip'ev, B. S. Semukhin. J. Surf. Investig. 4, 157 (2010). Crossref

14. S. A. Nevskii, S. V. Konovalov, V.E. Gromov. Tech. Phys. 56, 877 (2011). Crossref

15. S. V. Konovalov, V.I. Danilov, L.B. Zuev, R. A. Filipev, V.E. Gromov. Phys. Solid State. 49, 1457 (2007). Crossref

16. S. Kim, A. A. Polycarpou, H. Liang. Appl. Surf. Sci. 351, 460 (2015). Crossref

17. D. V. Orlova, V.I. Danilov, L. B. Zuev, O.S. Staskevich. Phys. Solid State. 58, 9 (2016). Crossref

18. I.S. Grigoriev, E.Z. Meilikhov. Handbook of Physical Quantities. CRC Press, USA (2002) 1548 p.

19. Y. Dekhtyar, S. Kronberga, M. Romanova. Int. J. Adhes. Adhes. 91, 19 (2019). $\underline{\text { Crossref }}$

20. Y. A. Khon, P.P. Kaminskii, L. B. Zuev. Phys. Solid State. 55, 1131 (2013). Crossref

21. X. Ye, Z. T. H. Tse, G. Tang, G. Song. Mater. Charact. 98, 147 (2014). Crossref

22. D. V. Orlova, L. B. Zuev, N.A. Ploskov. IOP Conf. Ser. Mater. Sci. Eng. 225, 012218 (2017). Crossref

23. B. Cappella, G. Dietler. Force-distance curves by atomic force microscopy. Lausanne, Universiti de Lausanne (1999) 104 p. Crossref

24. M. Long, H. J. Rack. Biomat. 19, 1621 (1998). Crossref

25. R. A. Filip'ev, S. V. Konovalov, V. A. Petrunin, V. E. Gromov. Russ. Metall. 2011, 89 (2011). $\underline{\text { Crossref }}$ 